\title{
Simulation of potential range expansion of oak disease caused by Phytophthora cinnamomi under climate change
}

\author{
Bergot Magali ${ }^{1}$, Cloppet Emmanuel ${ }^{1}$, Pérarnaud Victorine ${ }_{5}^{2}$, Déqué Michel ${ }^{3}$, \\ Marçais Benoit ${ }^{4}$, Desprez-Loustau Marie-Laure ${ }^{5}$
}

1 Météo-France, Direction de la Production, 42 avenue Gaspard Coriolis, 31057 Toulouse Cedex, France,

2 Météo-France, Direction des Systèmes d'Observation, 42 avenue Gaspard Coriolis, 31057 Toulouse Cedex, France,

3 Météo-France, Centre National de Recherche Météorologique, GMGEC/EAC, 42 avenue Gaspard Coriolis, 31057 Toulouse Cedex, France,

4 INRA, Laboratoire de pathologie forestière, 54280 Champenoux, France,

5 NRA, Centre de Bordeaux, UMR BIOGECO, Equipe de Pathologie forestière, BP 81, 33883 Villenave d'Ornon, France

\begin{abstract}
This study examines the effects of climate warming on one of the most widely distributed and destructive forest pathogens, Phytophthora cinnamomi. In Europe, the winter survival of the pathogen is the dominant cue for the development of the disease it causes to oaks, especially Quercus robur and $Q$. rubra. The potential pathogen and disease geographic ranges were compared in France between two reference periods, 1968-1998 and 2070-2099. Simulations were obtained by combining a physiologically based approach predicting the pathogen winter survival in relation to microhabitat temperature (in the phloem of infected trees) with a regionalized climatic scenario derived from a global circulation model. Positive anomalies in winter temperatures calculated with this scenario were in the range 0.5-5 $1 \mathrm{C}$ between the periods 2070-2099 and the 1968-1998, according to sites and months. As a consequence, higher annual rates of $P$. cinnamomi survival were predicted, resulting in a potential range expansion of the disease of one to a few hundred kilometers eastward from the Atlantic coast within one century. Based on this example, the study emphasizes the need of a better understanding of the impacts of global change on the biotic constraint constituted by plant pathogens.
\end{abstract}

Keywords: epidemiology, global warming, modelling, range shifts, risk assessment, temperature

\section{Introduction}

With accumulated evidence of climate change (IPCC, 2001), the effects on ecosystems, communities and populations have received increasing attention (Chuine et al., 2000; Bale et al., 2002; Beaumont \& Hughes, 2002; Peñuelas et al., 2002; Walther et al., 2002). This applies especially to forests, a major component of terrestrial ecosystems that play a prominent role in the dynamics of primary productivity and the global carbon cycle. The key issue of the contribution of forests to the terrestrial carbon sink, coupled with global change, has stimulated many studies on the potential impact of global change on phenology and growth at tree level and on net primary production at the ecosystem level (Murray et al., 1989; Leblanc \& Foster, 1992; Kramer, 1994a, b; Menzel \& Fabian, 1999; Chuine et al., 2000; Saxe et al., 2001; Cloppet, 2002). In this context, the disturbance caused by biotic agents, such as pathogens, may be a highly significant factor to be considered (Goudriaan \& Zadoks, 1995; Coakley \& Scherm, 1996; Chakraborty et al., 1998; Coakley et al., 1999; Malmström \& Raffa, 2000; Logan et al., 2003; Pérarnaud et al., 2003). Pathogen-induced diseases are strong forces 
that affect ecosystem structure and functioning via population vitality and community diversity, as demonstrated in undisturbed environments (Augspurger, 1984; Van der Putten et al., 1993; Dobson \& Crawley, 1994; Hansen \& Goheen, 2000; Gilbert, 2002) and also exemplified in past and current epidemics (Grente, 1961; Anagnostakis, 1987; Weste \& Marks, 1987; Harvell et al., 2002). Furthermore, the impact of many diseases is likely to increase with global warming due to more favorable conditions for pathogen development (survival, number of cycles per year) and higher/faster migration and adaptation potentials in pathogens than in plants, especially trees (Goudriaan \& Zadoks, 1995; Coakley \& Scherm, 1996; Chakraborty et al., 1998; Coakley et al., 1999; Davis \& Shaw, 2001; Etterson \& Shaw, 2001; Saxe et al., 2001; Harvell et al., 2002, Logan et al., 2003). Of critical importance are the potential shifts in pathogen geographic ranges, putting them into contact with new host populations or species. Potential disease outbreaks as severe as those observed following pathogen imports might then be expected (Harvell et al., 2002).

However, studies on potential changes in the frequency or extent of plant and especially forest diseases in relation to global change are still relatively scarce (Chakraborty et al., 1998; Patterson et al., 1999; Marçais et al., 2001). The fact that plant diseases are strongly influenced by weather factors is amply documented, most often at a seasonal or annual resolution scale (i.e. Coakley, 1988; Coakley et al., 1988; Johnson et al., 1996). Little is known at larger temporal scales chiefly because of a lack of reliable long-term disease records, except for a few examples (Houston \& Valentine, 1988; Scherm \& Yang, 1995; Jahn et al., 1996). Extrapolating to future climate is even more difficult given the necessity of functional models of climate-disease relationships integrated with relevant predicted meteorological variables (Scherm \& van Bruggen, 1994; Chakraborty et al., 1998; Coakley et al., 1999). Most previous studies that focus on plant disease under climate change have used an empirical approach (biogeographical modelling) and simplistic climate change scenarios (uniform changes in space and time of mean temperatures) (Podger et al., 1990; Brasier \& Scott, 1994; Coakley \& Scherm, 1996; Booth et al., 2000).

Phytophthora cinnamomi Rands. is one of the most devastating forest pathogens worldwide (Zentmyer, 1980) and offers a unique example for the study of longterm past and future impacts of climate on disease. P. cinnamomi is a soil-borne Oomycete (previously considered as lower fungi and now classified in Chromista, Kirk et al., 2001), affecting a wide range of hosts, mostly woody species. Primary symptoms caused by the pathogen are root, collar and sometimes stem necroses, resulting in two main disease types: declines and stem cankers. P. cinnamomi is thought to be native to Southeast Asia, but it is now recorded in most temperate to tropical areas and is responsible for severe crop diseases and strong disturbances in natural communities (Zentmyer, 1980; Shearer \& Tippett, 1989; Erwin \& Ribeiro, 1996). In Europe, the main species affected are chestnut and oaks (Moreau \& Moreau, 1952; Grente, 1961; Brasier et al., 1993; Robin et al., 1998; Vettraino et al., 2002) and nursery plants (Vegh \& Bourgeois, 1975). In Quercus rubra and Q. robur, the initial lesions at root or collar level develop upwards in the trunk and the disease expression is typically a bleeding trunk canker, therefore named 'ink disease'. Since P. cinnamomi essentially develops in inner cortical tissues and not in the wood, oaks keep track of past infections in the form of necroses at the cambium level (scars). Dendrochronological analyses can therefore be applied and provide disease development data over long periods (Robin et al., 1992a, b). Disease development was shown to be strongly hampered by cold winters (Robin et al., 1992b; Marçais et al., 1996), in agreement with the known sensitivity of $P$. cinnamomi to frost (Benson, 1982). The hypothesis that lethal frost effects on the pathogen could be a major factor limiting disease range in oaks was put forward by Delatour (1986). It was based on the fact that the geographic distribution of ink disease in oaks is still restricted to a small part of its host range more than a century after the supposed introduction of the pathogen in France (1860) and 40 years after its first mention in oaks (Moreau \& Moreau, 1952). This contrasts with the much larger distribution of the pathogen expressed on other hosts where primary symptoms mainly occur in the root system, especially chestnuts and nursery plants. Most French chestnut growing areas were affected within 40 years after the first disease mention in this species (Grente, 1961). P. cinnamomi is largely distributed in nurseries in France (Vegh \& Bourgeois, 1975) and present in other European countries, including northern ones like Germany (Themann et al., 2002). $P$. cinnamomi might also be more widely distributed in oak stands than estimated from canker symptoms, as suggested by a few positive isolations from the rhizosphere soil of oaks exhibiting no canker symptoms in Central France (unpublished results). Indeed, winter survival is likely to be more critical when the pathogen overwinters in the aerial system than in roots, as freezing temperatures seldom occur in soils below $10-30 \mathrm{~cm}$ deep in temperate regions. A model of $P$. cinnamomi survival in oak trunks as a function of air temperature and tree characteristics was then developed. The actual disease development (from dendrochronological data) was significantly positively related to the 
predicted pathogen survival (Marçais et al., 1996). These observations and results gave strong support to the idea that poor winter pathogen survival is a key process limiting canker disease in oaks. Although several variables other than winter temperature are known to affect canker development, such as summer temperature, precipitation regime, tree susceptibility, etc. (Shearer \& Tippett, 1989; Robin et al., 1992b; Marçais et al., 1993), these would act only secondarily, as modulating factors. A climatic disease risk mapping based on P. cinnamomi survival was then developed by using the survival model integrated with meteorological data from a past 30-year period (Bergot et al., 2001; Desprez-Loustau et al., 2002). Three high-risk areas were identified in France and they were characterized by a mild winter regime and included the known distribution range of the disease in oaks. The mapping relied on the French operational meteorological network, with approximately one station per $1000 \mathrm{~km}^{2}(30 \mathrm{~km} \times 30 \mathrm{~km})$. This fine spatial resolution can now be approached in recently developed regionalized climate change scenarios, as well as the subdaily time resolution needed by the model.

The aim of this study was to predict spatial and temporal quantitative changes in $P$. cinnamomi survival and to derive the potential range expansion of the disease it causes to oaks, under climate change. To this end, we used a process-based approach using a biological model integrated with a regionalized climatic scenario derived from a global circulation model (GCM).

\section{Materials and methods}

\section{Epidemiological model}

The model, described in Marçais et al. (1996), simulates the impact of frost on P. cinnamomi overwintering survival in the inner bark of infected trees. This survival is considered as a prerequisite to the pathogen's ability to cause a perennial canker in oak trunks, which results from repeated annual cycles of killing of the new tissues by the pathogen and callus formation by the tree around lesions. The model is based on 1) a transfer equation used to calculate the inner bark temperature (cambial temperature) from air temperature, 2) the summation of negative degree hours at cambium level from November 1 to March 31, and 3) the survival response to temperature of $P$. cinnamomi in inner bark, as determined from experimental studies. Input variables are tree characteristics (species and diameter) affecting the thermal transmission coefficient of trunks, and daily minimum and maximum air temperatures (from which hourly temperatures are derived). The model output is an annual survival rate (ASR) taking values from 0 (no survival) to 1 (full survival). The ability of ASR to predict annual canker growth (ACG) in the subsequent growing season was validated against long time series of disease data from 20 naturally cankered trees in four sites in South West France with ASR values computed for each tree $\mathrm{x}$ site $\mathrm{x}$ year. ACG was estimated as the difference between two successive years in the relative percentage of tree perimeter attacked, defined from measurements of the total perimeter and the sum of all lesion (scar) lengths on the annual ring. A significant positive correlation was obtained between ASR and the observed ACG. Very low ASR values (below 0.05), predicting no survival of $P$. cinnamomi, were indeed associated with complete canker healing (i.e. no lesions in the subsequent year); values comprised between 0.05 and 0.5 were mostly associated with negative ACGs (i.e. partial canker healing): this might be interpreted as low survival of the pathogen resulting in a limiting ability to compete with host growth and defences in colonizing new tissues. In contrast, ASR values above 0.5 were mostly associated with positive ACGs (i.e. canker extension). The ASR value of 0.5 therefore appeared as a threshold value above which disease development was not hampered by $P$. cinnamomi survival.

The epidemiological model was run with two thermal transmission coefficients, corresponding to the parameterization for $Q$. rubra and $Q$. robur. A slightly higher coefficient at equal diameter was obtained for $Q$. rubra than for $Q$. robur, in relation to a thinner and smoother bark. The two oak species are of major importance for forestry in temperate Europe, especially in France, the former as an introduced species extensively used for afforestation (Timbal et al., 1994), the latter as one of the major indigenous forest species (in France the most widely spread, with more than 2 million hectares). Both species are affected by ink disease caused by P. cinnamomi in only a small part of their geographic range, limited to south-western France according to available reports (Bergot et al., 2001; Desprez-Loustau et al., 2002, Fig. 1), and probably adjacent areas of Spain.

\section{Climatological data}

Historical data. Past climatological data were collected from 503 meteorological stations over France, at an elevation below $1000 \mathrm{~m}$ above sea level. These stations are automatic and can provide 
minimum and maximum daily temperature data over at least a 30 -year period. The study period is 1968-1998 and represents a compromise between the length of the period and the density of the ground stations network. The selection of this period did not take into account the severe frosts reported during winters 1956 and 1962 but did include the exceptionally cold events of January 1985 and January 1987.

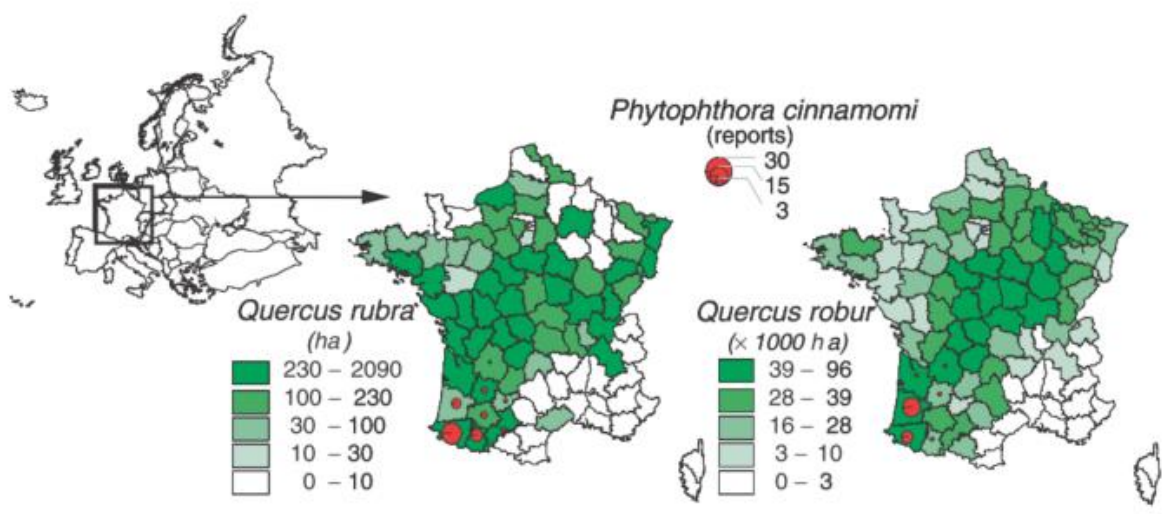

Fig. 1 Distribution of Phytophthora cinnamomi in oaks (December 2002): data from INRA and the Département de la Santé des Forêts database (visual symptoms + isolations in most cases). Forest data from Inventaire Forestier National (http://www.ifn.fr/).

Simulated data. Meteorological data were extracted from the ARPEGE model developed by METEO-FRANCE (Déqué et al., 1994, 1998). This is a GCM describing the time evolution of the atmosphere by solving fluid dynamics equations. It is used as a meteorological forecast model and also for climatological simulation. The calculation of radiation includes the effect of four greenhouse gases $\left(\mathrm{CO}_{2}, \mathrm{CH}_{4}, \mathrm{~N}_{2} \mathrm{O}\right.$ and $\left.\mathrm{CFC}\right)$ in addition to water vapor and ozone, and of five aerosol types (land, sea, urban, desert and sulfate) in addition to background aerosols. The model was forced by an effective greenhouse effect corresponding to the provisional IPCC B2 scenario (IPCC 2001). The main assumptions of the emission scenario and the model details can be briefly summed up as follows. A more complete description of the regionalized climate scenario can be found in Déqué et al. (1998).

B2 scenario. The IPCC Special Report on Emission Scenarios (SRES) provides 40 different scenarios that are deemed equally likely. These scenarios have been constructed to explore future developments in the global environment with special reference to the production of greenhouse gases and aerosols, from hypotheses on possible demographic, politico-economic, societal and technological future. For the Third Assessment Report, the IPCC facilitated the conversion of two of these emission scenarios (A2 and B2) into concentration scenarios for use in climate simulations. The B2 scenario is a moderate climate change scenario that envisions a $70 \%$ increase in the current effective $\mathrm{CO}_{2}$ concentration by 2100 . The B2 scenario envisions a slow population growth (10.4 billion by 2100) with a more rapidly evolving economy and more emphasis on environmental protection. It therefore produces lower emissions and less future warming than the A2 scenario for example $\left(\mathrm{CO}_{2}\right.$ emissions in 2100 of 14 and 29 Gt C in A2 and B2, respectively, with whole range including all scenarios between 5 and 29).

The regionalized climate scenario. IPCC recommends the use of downscaled models in order to assess climate change, climate variability and extreme events at regional scale. In this work the model had to take into account the fine spatial variability of surface properties of agricultural and forested production systems. Using a coupled ocean-atmosphere GCM at regional scale is currently unrealistic. Two experiments using different experimental setups were then performed with the ARPEGE model in order to allow downscaling. The first consisted of a pair of coupled coarse resolution 150-year simulations corresponding to 1950-2100. The atmospheric model was run with a uniform T63 truncation (which is roughly equivalent to a $280 \mathrm{~km}$ regular mesh) and a high vertical resolution with 45 levels. The first simulation was a control simulation in which the greenhouse gas concentrations remained constant (1950 radiative forcing). For the second simulation greenhouse gas concentrations were prescribed to the models according to IPCC historical data (for the period 1950 to present) and scenarios (for the second half of the simulation). In a second step, several time-slice 
simulations were performed with a variable resolution model corresponding to 1960-2099. From 1960 to 1999 , sea surface temperature (SST) boundary conditions were prescribed to the model according to monthly mean observed SST (Smith et al., 1996). From 2000 to 2099 artificial monthly SSTs were created by adding anomalies from the above-described coupled scenario to observed SSTs. The variable resolution configuration had a T106 truncation instead of T63 and 31 vertical levels. The variable resolution allowed simulation of fine-scale information over a regional area. The stretching factor was 3 and the pole of stretching was approximately at the center of the Mediterranean basin (40 $1 \mathrm{~N}, 121 \mathrm{E})$ (Gibelin \& Déqué, 2003). As a result the mesh size is about $50 \mathrm{~km}$ over France (a 0.51 0.51 resolution) and about $500 \mathrm{~km}$ over the Pacific Ocean. This version uses semi-Lagrangian advection and a two time-level discretization. Vertical discretization uses hybrid coordinates (Simmons \& Burridge, 1981). The time step is $30 \mathrm{~min}$. Most output data are daily but some parameters are provided every $6 \mathrm{~h}(0,6,12$ and $18 \mathrm{~h})$. Output data used in this study are $2 \mathrm{~m}$ high minimum and maximum daily temperatures.

Integration of simulated climatological data in the epidemiological model. Simulated climatological data were used for the period 2070-2099. The choice of a 100-year time span between the two study periods was dictated by the low-frequency variability of local climate. Although the global mean temperature increases slowly and regularly along the 21 st century in the model, regions like Europe experience fluctuations due to natural processes involving oceanic circulation. In order to study the response of the 2020s or 2040s, ensembles of coupled scenarios, which do not yet exist, would be necessary to filter out internal variability. Beyond 2060, the signal due to radiative forcing is larger than the noise due to natural variability. For the above reason, the scientific community has decided to focus on climate simulation at the end of the 21 st century.

The limiting ability of current GCMs, including the model we used to reproduce the natural variability of climate, made it difficult in turn to compare the 2070- 2099 study period with the 19681998 reference period. To cope with this difficulty, the anomaly method was used. This method mitigates the limitations of the model by keeping the present natural variability of climate while taking into account the global warming at a regional and temporal scale. Monthly mean anomalies of minimum and maximum temperatures were computed for each mesh point from November to March by calculating differences between monthly mean minimum and maximum temperatures extracted from the 1968-1998 to 2070-2099 variable resolution simulation, respectively. These anomalies were then interpolated to the coordinates of the 503 meteorological stations with a $1 / \mathrm{r}^{2}$ interpolation using the five closest grid points. Adding these mean monthly anomalies to the observed daily temperature data in the 1968-1998 period created simulated minimum and maximum daily temperatures for the 2070-2099 period. These simulated data were then used as input data in the epidemiological model for the 2070-2099 period.

\section{Mapping of pathogen survival and disease risk}

P. cinnamomi ASR was calculated for the 503 points corresponding to the meteorological stations and for each period (1968-1998 and 2070-2099), using the measured and simulated temperature data, respectively, as inputs in the epidemiological model. In order to synthesize information and to make it more easily interpretable in terms of disease risk, a frequential analysis was carried out to obtain survival rate patterns at each point for both oak species. These patterns were characterized by the frequencies of ASR lower than or equal to the two above-mentioned threshold values: $F_{0.05}$ and $F_{0.5}$, for $A S R=0.05$ and $A S R=0.5$, respectively. $F_{0.05}$ is related to the probability of $P$. cinnamomi survival. Its mapping will therefore provide a potential range of the pathogen itself. The second index, $F_{0.5}$, based on the survival threshold value not limiting for disease expression, was used to estimate the probability of canker occurrence. The significance of $F_{0.5}$ values in terms of disease risk was based on a study with disease data from a systematic survey of red oak stands in the geographic range of the disease (South west) by the French Forest Health Service (DSF). Stands with a calculated $F_{0.5}<10 \%$ were all affected, with a mean incidence of $15 \%$ cankered trees; stands with $F_{0.5}$ comprised between $10 \%$ and $40 \%$ were affected at $47 \%$ with a mean canker incidence within stands of $8 \%$; no stand with $\mathrm{F}_{0.5}>40 \%$ was found with disease symptoms. Disease risk was then considered to be high, moderate or null for $\mathrm{F}_{0.5}<10 \%, 10 \%<\mathrm{F}_{0.5}<40 \%$ and $\mathrm{F}_{0.5}>40 \%$, respectively (DesprezLoustau et al., 2002).

For each species, $\mathrm{F}_{0.05}$ and $\mathrm{F}_{0.5}$ were then spatialized on the French metropolitan territory. In the cartography software used (Arcview 3.2), the layouts were carried out from the interpolation of $F_{0.05}$ and $F_{0.5}$ to a $4 \mathrm{~km} \times 4 \mathrm{~km}$ homogeneous grid. The estimated value of the $P$ parameter was calculated using a $1 / \mathrm{r}^{2}$ interpolation and the nearest five stations: 


$$
P(X)=\frac{\sum_{i=1}^{i=5} P\left(Y_{i}\right) / \operatorname{Distance}\left(X Y_{i}\right)^{2}}{\sum_{i=1}^{i=5} 1 / \operatorname{Distance}\left(X Y_{i}\right)^{2}}
$$

where $X$ is the position of the point where the $P$ parameter has been interpolated, $Y_{i}$ is the position of one of the five meteorological stations for which data is available for the day in progress and Distance $\left(X Y_{i}\right)$ is the distance between the positions of $X$ and the $Y_{i}$ stations calculated from the Lambert II co-ordinates.

Table 1 Mean monthly anomalies of temperatures between periods 2070-2099 and 1968-1998 over the whole study area

\begin{tabular}{lll}
\hline & $\begin{array}{l}\text { Minimal temperature } \\
\text { anomaly }\left({ }^{\circ} \mathrm{C}\right)\end{array}$ & $\begin{array}{l}\text { Maximal temperature } \\
\text { anomaly }\left({ }^{\circ} \mathrm{C}\right)\end{array}$ \\
\hline November & 1.97 & 2.15 \\
December & 1.62 & 1.76 \\
January & 1.80 & 2.14 \\
February & 1.35 & 1.87 \\
March & 1.44 & 2.00 \\
\hline
\end{tabular}

\section{Results}

\section{Spatial and temporal distribution of the winter temperature anomalies}

Monthly temperature anomalies between the 2070-2099 and 1968-1998 periods were always positive whatever the area or month, denoting a warming trend of approximately $1.81 \mathrm{C}$ for the mean temperature during the winter period. Monthly anomalies were higher for maximum than for minimum temperatures, on average (Table 1). However, spatial and temporal variation in anomalies was obtained, as clearly evidenced in Figs 2 and 3. November showed the highest and spatially most homogeneous anomalies for both minimum and maximum temperatures. In most other months and for both types of temperatures, the anomalies increased in a northwest to southeast gradient. The highest anomalies were obtained in the high elevation areas of the Alps, in December and January and to a lesser extent February, for minimum temperatures. Sharp gradients in mountainous areas were also observed for anomalies in maximum temperatures, with the highest values in the medium elevations and the lowest in the high elevations in January, February and March. This behavior is explained by the so-called snow-albedo feedback. Some mountainous areas are snow-covered in the control and snow-free in the scenario because of the warming. The temperature difference in these areas can be much larger than over areas that are snow-free or snow-covered in the two time slices.

\section{Mapping of $P$. cinnamomi survival pattern and disease risk}

Whatever the oak species and location, a general decrease in the frequency of years potentially unfavorable to $P$. cinnamomi survival ( 0.05 threshold) and disease expression ( 0.5 threshold) was obtained between the two study periods (Fig. 4). For a vast majority of locations ( $86 \%$ and $79 \%$ for $Q$. robur and $Q$. rubra, respectively), $F_{0.05}$ was projected to decrease by at least twofold. Locations completely unsuitable for $P$. cinnamomi survival in oaks (ASR $<0.05$ in $90 \%$ years) may almost disappear in 2070-2099. Similarly, $\mathrm{F}_{0.5}$ was strongly reduced in 2070-2099 as compared with 19681998. Locations with a moderate disease risk $\left(10 \%<\mathrm{F}_{0.05}(1968-1998)<40 \%\right)$ may become even more favorable to disease, but, more remarkably, many locations previously excluded from disease risk $\left(40 \%<\mathrm{F}_{0.5}(1968-1998)<75 \%\right)$ are expected to become at risk $\left(\mathrm{F}_{0.5}<(2070-2099)<40 \%\right)$, for both oak species. As a whole, the distribution of $F_{0.5}$ for the 503 stations in the three risk classes (high - moderate - null) changes from 20-25-55\% to 36-37-27\% for red oak, and from 26-25-49\% to 40 44-16\% for pedunculate oak, between 1968-1998 and 2070-2099, respectively.

As a result, a geographic expansion of the areas potentially favorable to $P$. cinnamomi survival and disease development is predicted (Figs 5 and 6). For red oak, the zones most favorable for P. cinnamomi survival (in $90 \%$ of years) may show an approximately $100 \mathrm{~km}$ extension eastward from the Atlantic coast. The northward extension from the Mediterranean zone is confined to the Rhone valley, between the mountainous zones of the Massif Central and the Alps. The same and even amplified trends are observed for $P$. cinnamomi survival in pedunculate oaks. As a consequence of 
higher $P$. cinnamomi survival, zones at high disease risk $\left(F_{0.5}<10 \%\right)$ may extend essentially eastward from the Atlantic coast by approximately $100 \mathrm{~km}$, for both oak species. The potential expansion of moderate risk zones $\left(10 \%<\mathrm{F}_{0.5}<40 \%\right.$, ) is higher, especially in the north-central part of the country. Finally, zones previously considered as nonsuitable for disease development $\left(\mathrm{F}_{0.5}>40 \%\right)$ may display a dramatic decrease from approximately two-thirds to one-third ( $Q$. rubra) and one-half to one-quarter (Q. robur) of total country surface area.

(a)

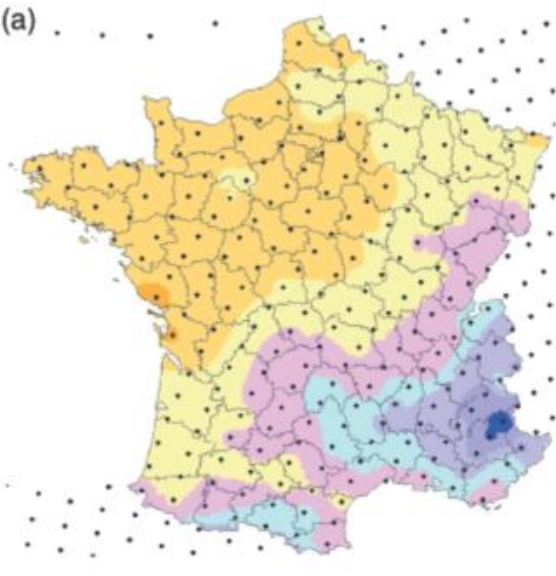

(c)

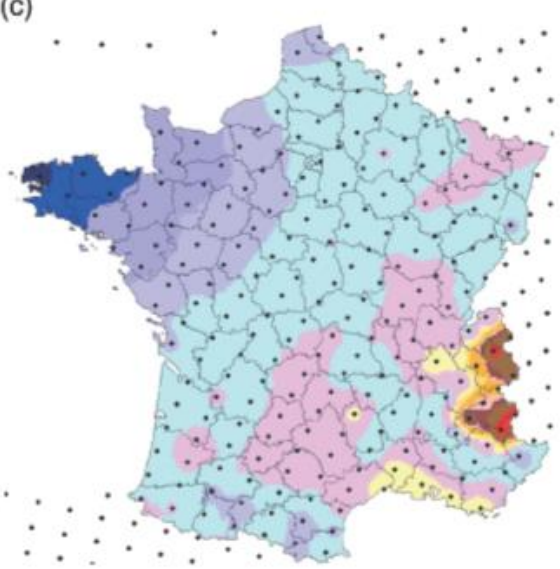

(e)

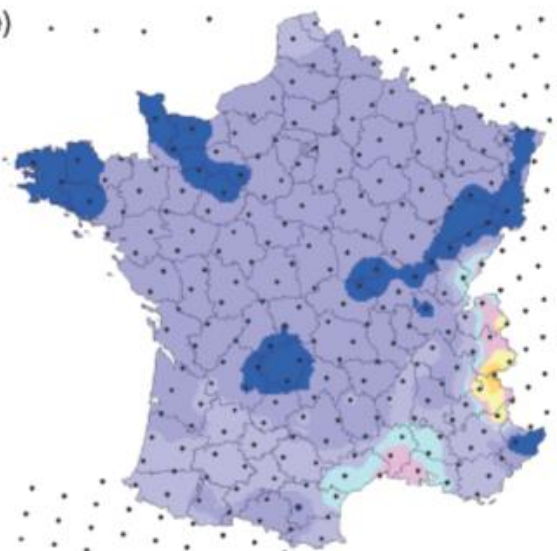

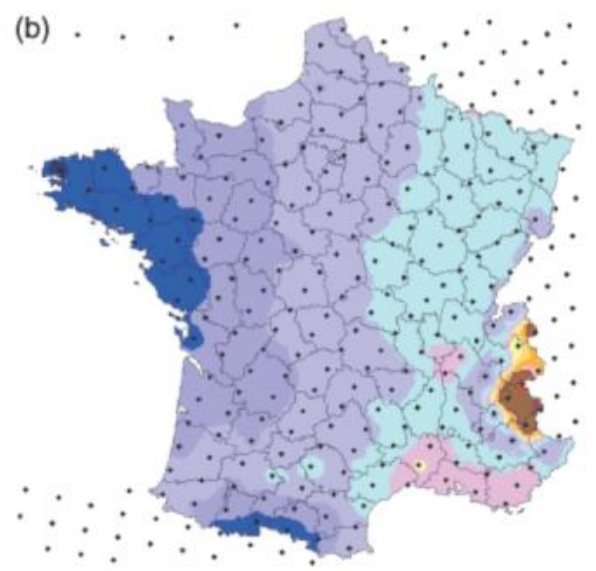
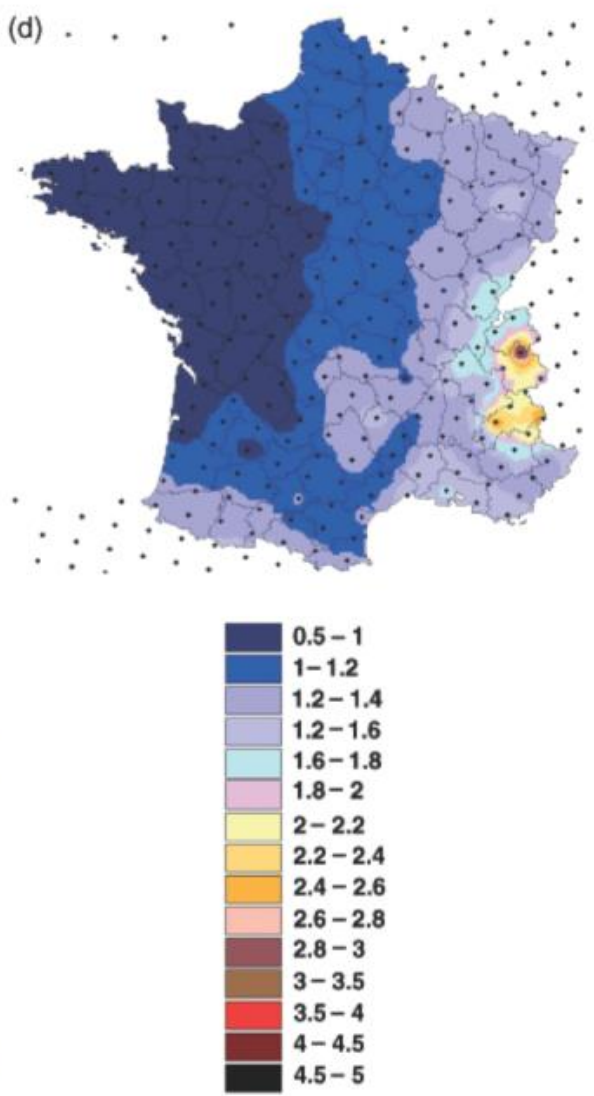

Fig. 2 Anomalies of mean monthly minimal temperatures in November (a), December (b), January (c), February (d) and March (e) between periods 2070-2099 and 1968-1998, from data simulated by the Arpege model. 
(a)

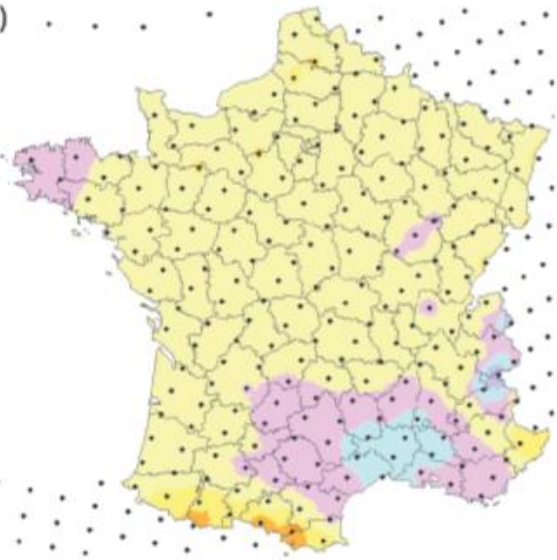

(c)

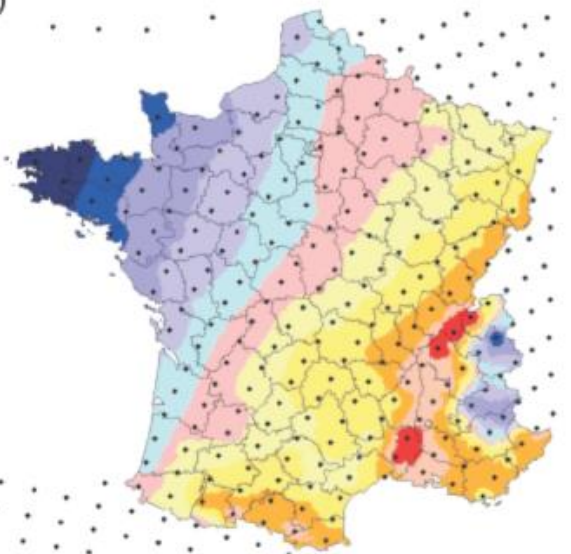

(e)

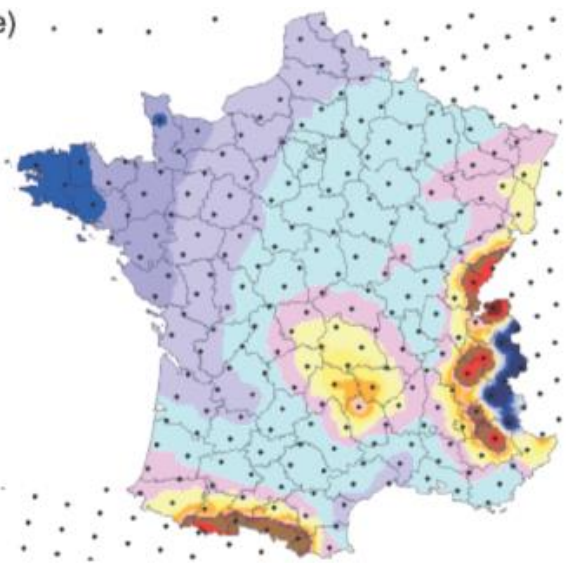

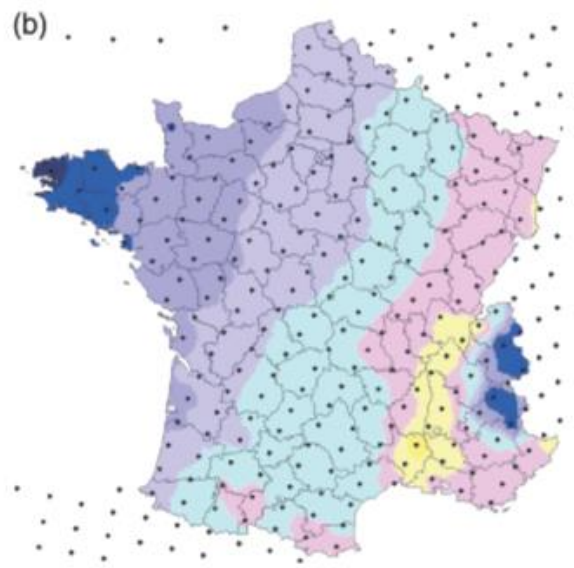

(d)

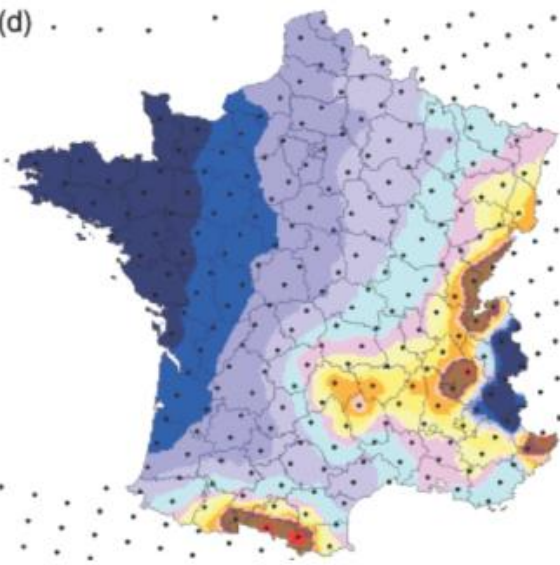

Fig. 3 Anomalies of mean monthly maximal temperatures in November (a), December (b), January (c), February (d) and March (e) between periods 2070-2099 and 1968-1998, from data simulated by the Arpege model.

\section{Discussion}

To our knowledge, this is the first study integrating a state-of-the-art regionalized climatic scenario down-scaled from a GCM with a process-based biological model to assess the potential impact of climate change on a plant disease. The example of $P$. cinnamomi is of particular significance given its economical and environmental importance. As the biological model was based on the effects of climate on overwintering as a key stage of the biological cycle of the pathogen and on the expression of disease, the conclusions drawn may apply to some extent to other pathosystems with such a critical stage. We will first discuss methodological aspects related to the use of the climatic scenario, then the results themselves. 

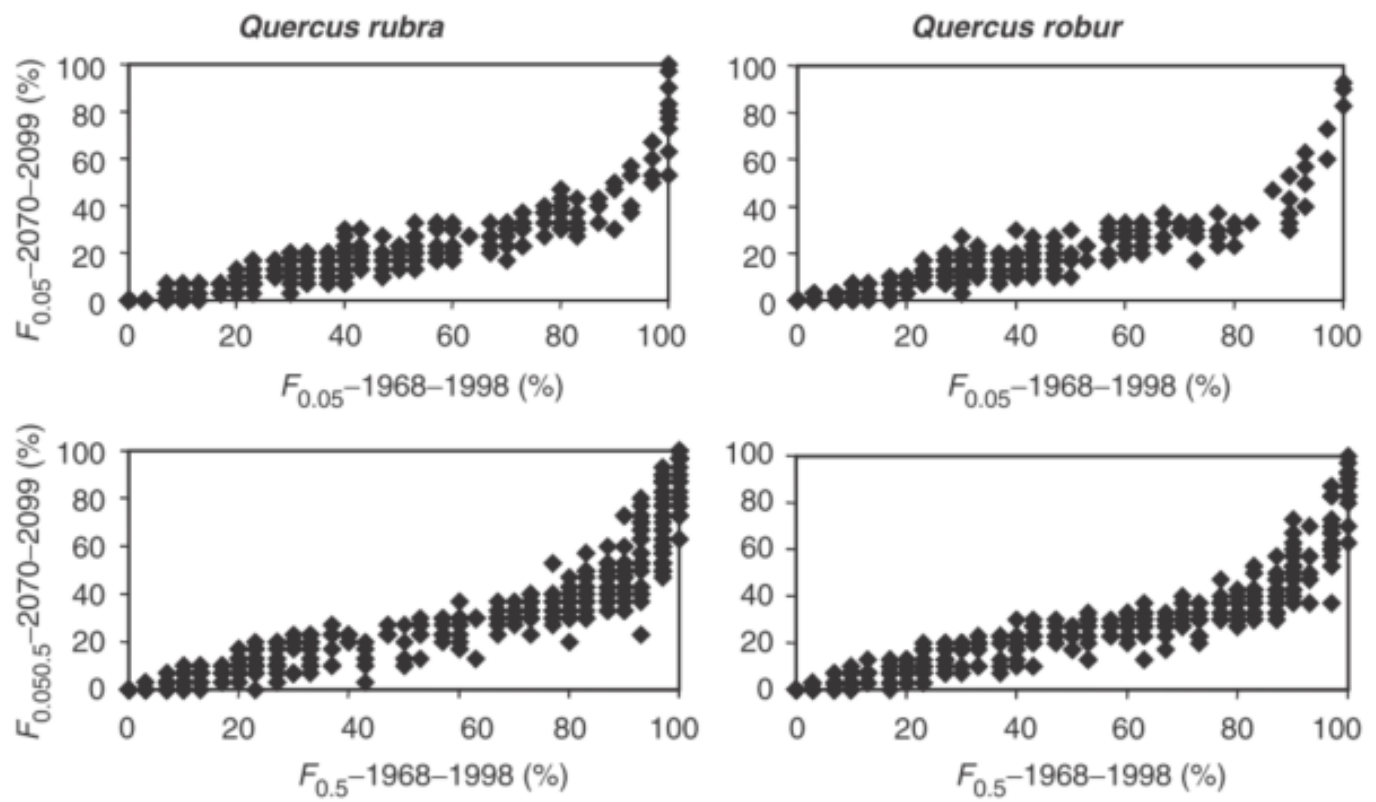

Fig. 4 Distribution of years in periods 1968-1998 and 2070-2099 with Phytophthora cinnamomi annual survival rate below the 0.05 and 0.5 thresholds: $F_{0.05}$ and $F_{0.5}$, respectively.

\section{Methodology}

The known limitation of current GCMs, including the climatic scenario used in this study, to reproduce the natural variability of climate is a significant drawback for biological modelling, given the nonlinear response to temperature of most biological functions (Scherm \& van Bruggen, 1994). It is even more unsatisfactory when biological processes affected by extreme climatic events, such as survival by temperature in this study, are addressed. We tried to cope with this difficulty by using the anomaly method. A further improvement might be a more sophisticated calculation of anomalies, defining the exact nonlinear function between the two series of data. Variable anomalies, with higher values at the extreme limits of the temperature distribution as compared with central values, might be obtained.

It is noteworthy that the model we used predicted a lower increase in minimum than in maximum temperatures (Cloppet, 2002), contrary to low-resolution GCMs (IPCC, 2001) and to 20th century observed trends, and in winter as compared with summer, in agreement with other RCMs (Machenhauer et al., 1998). The reason may lie in the treatment of soil moisture in the model. The main impact in the scenario, besides air warming, is soil drying out. The soil model has a memory of a few seasons. Drier soil implies lesser cooling by evaporation during the day and thus higher maximum temperatures. The difference between GCMs can also be explained by cloud feedback. Clouding is a crucial factor, having both warming (especially on minimum temperatures) and cooling effects (especially on maximum temperatures), but still constitutes a major uncertainty in GCMs (Loehle, 1996).

\section{scenario \\ Impact on $P$. cinnamomi survival and oak disease of the regionalized climatic}

Despite the limitations discussed above, it is reasonable to assume the soundness of predicted trends, if not of their extent of accuracy. Among predicted climatic changes brought about by global change, temperature increase is arguably less subject to uncertainty. Potentially important effects of an increase in the lower range of temperatures have been predicted, especially on winter events and early spring biological events (Bale et al., 2002; Harvell et al., 2002; Walther et al., 2002). Indeed, an advanced timing in the nesting of birds or in the phenology of plants and animals has already been observed, most probably reflecting the recent increase in temperatures (Roy \& Sparks, 2000; Pen uelas et al., 2002; Walther et al., 2002). Global warming is also projected to favor range shifts, especially poleward migrations, for many species for which temperatures are the main limiting factor of geographic distribution (Parmesan et al., 1999; Saxe et al., 2001; Bale et al., 2002; Harvell et al., 2002). Our results with $P$. cinnamomi are consistent with the theoretical assessments of higher winter 
survival of many pest and pathogen species (Harvell et al., 2002). The resulting potential range expansion of the disease (canker symptoms) of one to a few hundred kilometers in one century is in the same order of magnitude the projected potential range shifts in the next century for example for plants (Davis \& Shaw, 2001; Walther et al., 2002). This shift in the climate envelope, even with a moderate greenhouse effect scenario such as B2, is far beyond the migration rates inferred from fossil records in response to past quaternary climate changes, indicating much faster climatic change in the recent times (Davis \& Shaw, 2001).

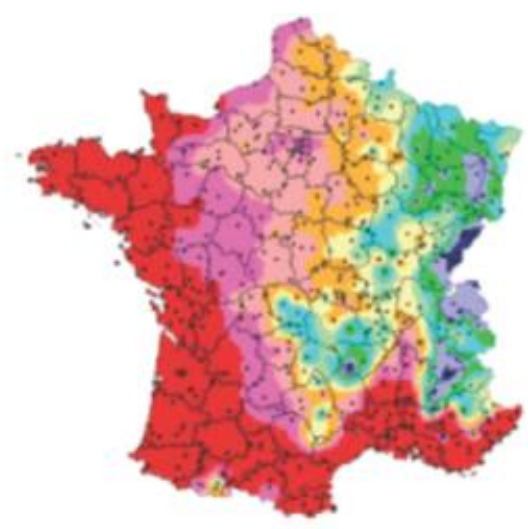

$F_{0.05}$

$1968-1998$

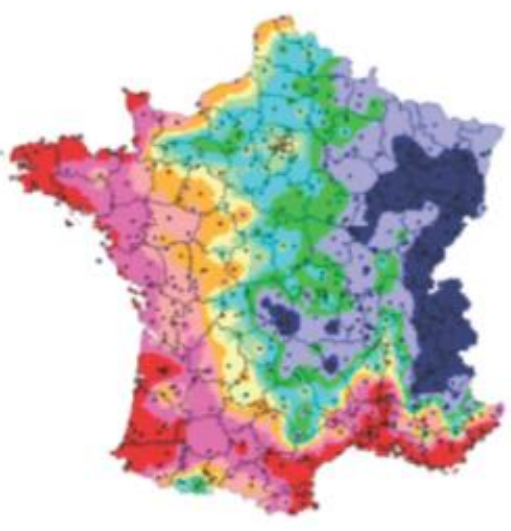

$F_{0.5}$

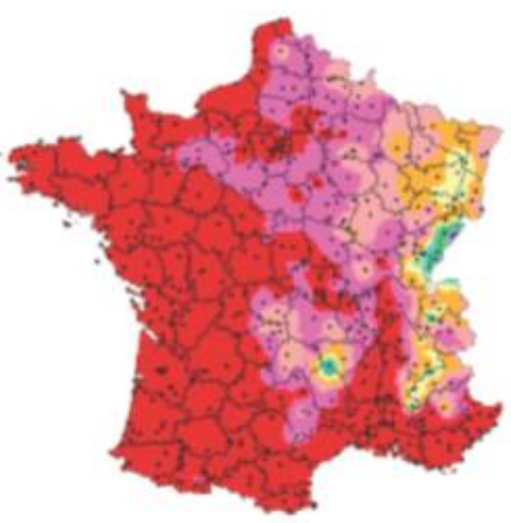

2070-2099

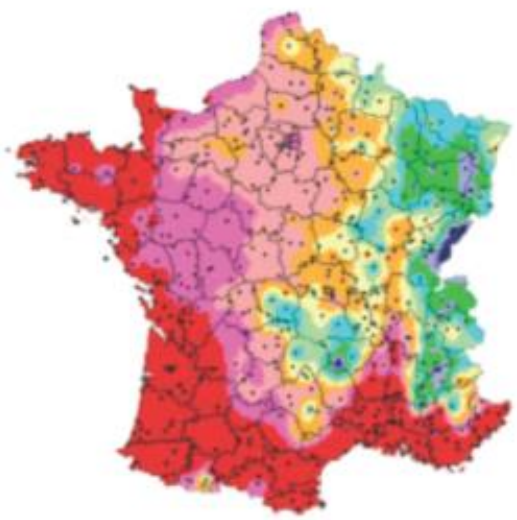

2070-2099

Fig. 5 Mapping of $F_{0.05}$ and $F_{0.5}$ in Quercus rubra (frequencies of years with Phytophthora cinnamomi annual survival rate below the 0.05 and 0.5 thresholds) for periods 1968-1998 and 2070-2099.

Our results are also consistent with the trends projected by Brasier \& Scott (1994) for the same species at a larger scale, using the climate matching software Climex. However, a later version of this software displayed a higher baseline for disease in the present climate, after a change in parameters (Sutherst et al., 1999). In these studies, it was mainly the decline disease induced by $P$. cinnamomi, for example, in chestnut or evergreen oaks (Brasier et al., 1993; Robin et al., 1998), which was considered. In this case, the overwintering microhabitat is in the roots and soil and, given the high buffering capacity of soil, the constraint of low temperatures on the pathogen survival is less likely to be important than for the aerial disease. An improvement in soil temperature modelling is needed to extend our survival-based model to this disease stage. Higher survival in soil and roots could also affect ink disease in oaks since re-infection of the trunk from root and collar infections might occur more frequently and more intensively.

Our mechanistic approach, although incomplete, may offer better predictive ability than the commonly used empirical approaches, based on statistical relationships between environment and disease, in particular bioclimatic modelling (Podger et al., 1990; Brasier \& Scott, 1994; Coakley \& Scherm, 1996; Sutherst et al., 1999; Booth et al., 2000; Logan et al., 2003). Furthermore, a 
prerequisite of biogeographical modelling is that the distribution used for the derivation of parameters describing the bioclimatic range of the species has reached the limits of its potential climatic envelope (Beaumont \& Hughes, 2002). This condition is most probably not met for P. cinnamomi ink disease in oaks. The disease has only been occasionally reported outside Europe, in the United States (Mircetich et al., 1977). In Europe, as previously mentioned, the disease has been recorded in only a small part of its oak host range. In addition, $P$. cinnamomi has a much wider distribution on other hosts, such as chestnuts, or in nurseries (Grente, 1961; Vegh \& Bourgeois, 1975; Zentmyer, 1980). The stronger climatic constraint on pathogen survival in trunks (for oaks), than in roots or soil (for most other hosts), is the central hypothesis of our modelling approach and is probably an important explaining factor in the epidemiology of the disease (Delatour, 1986; Marçais et al., 1996). However, the limited extent of ink disease in oaks may be partly explained by two other sets of factors: (1) $P$. cinnamomi, which is an introduced organism in Europe, may exhibit a more restricted distribution (i.e. less frequent occurrence) in extensively managed oak stands as compared with chestnut groves or nurseries. The dissemination of the pathogen by human activities is a well-established factor of its range expansion after introduction in an area (Podger \& Newhook, 1972). (2) Oaks are less susceptible to $P$. cinnamomi than chestnuts, and $Q$. robur (the most widely occurring oak species) less so than $Q$. rubra. Furthermore, symptoms in trunks cannot be observed before the trees are at least 10-year old and are better expressed when 30-60-year old (Robin et al., 1992a). It is remarkable that the Basque country, where the disease is the most frequent and severe, presents highly favorable climatic conditions for P. cinnamomi (moist and warm climate) but is also the area colonized most early by $P$. cinnamomi (Moreau \& Moreau, 1952) and intensively planted with $Q$. rubra (Timbal et al., 1994).
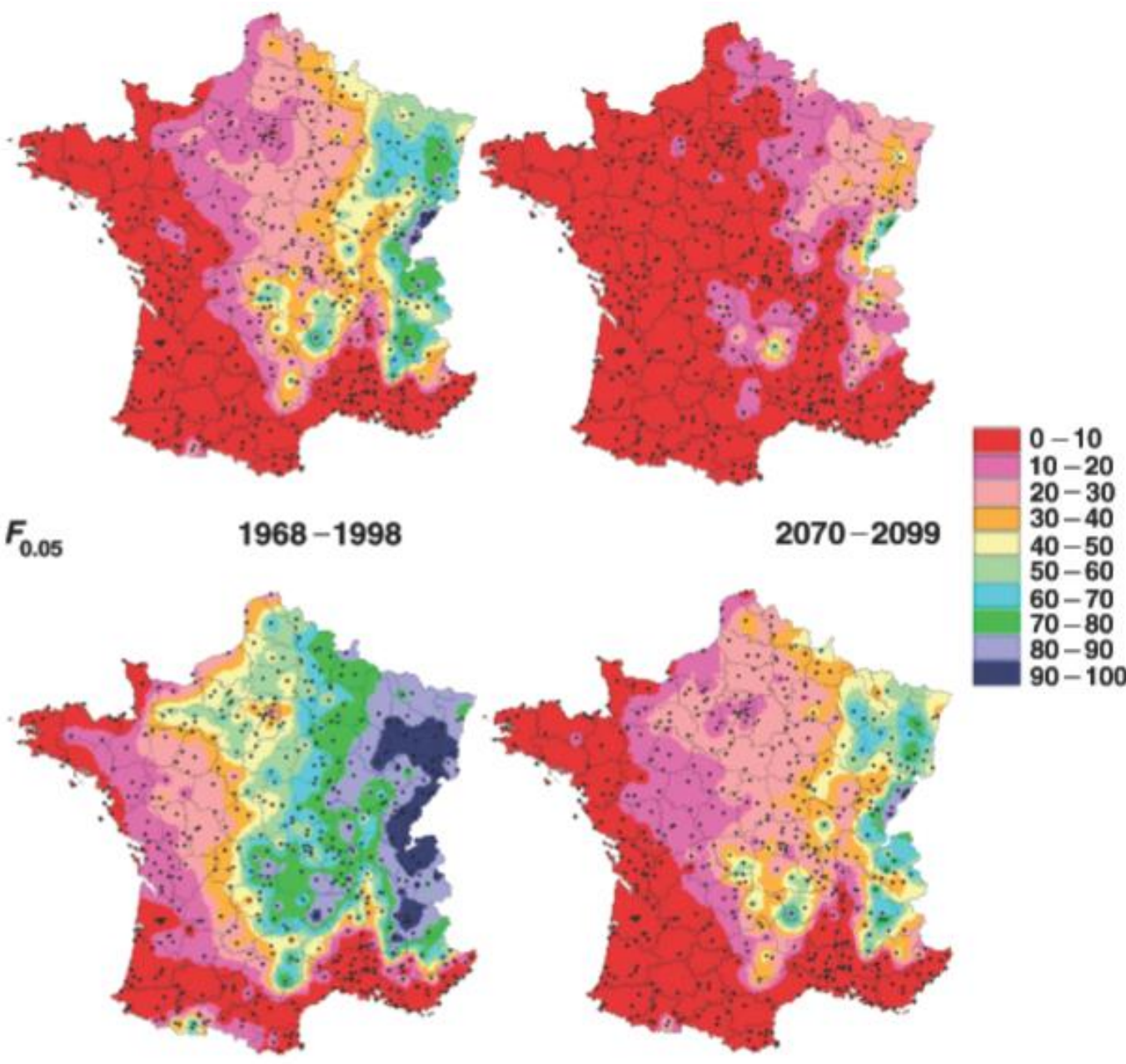

$F_{0.5}$

$1968-1998$

2070-2099

Fig. 6 Mapping of F 0.05 and F 0.5 in Quercus robur (frequencies of years with Phytophthora cinnamomi annual survival rate below the 0.05 and 0.5 thresholds) for the 1968-1998 and 2070-2099 periods. 
In the perspective of the use of forests, especially plantation forests, as a carbon sink to mitigate the greenhouse effect, management, including pest and disease control, is a critical issue (Saxe et al., 2001). Modelling and simulations to provide decision tools are all the more important when short-term adjustments in management practices are impossible in perennial crops. Disease control is also more difficult than in annual crops, even more so for soil-borne pathogens that may persist in soil for long periods, even without susceptible hosts. In this context, pathogen and disease zoning, coupled with quarantine and hygiene methods, should be of increased interest (Shearer \& Tippett, 1989; Coakley \& Scherm, 1996), especially for generalist pathogens, such as $P$. cinnamomi, which may represent an important threat (Harvell et al., 2002). Disease zoning will have to consider not only climatic constraints but also all factors conditioning pathogen spread in their climatic envelopes, especially resource availability (susceptible hosts) and dispersal (Walther et al., 2002). The selection of appropriate forest species/varieties for plantations and the application of preventive methods limiting pathogen dispersal will be important measures for reducing disease impact in new areas at risk due to climate change. Our results further stress the need of a strict prophylaxis to avoid the dissemination of pathogens in previously healthy areas, especially through the use of nursery-grown plants (Shearer \& Tippett, 1989; Robin \& Desprez-Loustau, 1999). The recent reports of $P$. cinnamomi on pedunculate oaks mostly came from planted stands, while the disease has been very seldom observed in naturally regenerated stands (Maugard, 1997).

This study is a first step in the iterative process of risk mapping of the ink disease of oaks caused by $P$. cinnamomi, especially in the context of global change. Only the effects of winter temperature on a key stage of the life cycle of the pathogen were considered. Once this determinant factor is removed, other climatic variables, such as summer temperatures and hydrologic variables, which will also be affected by global change, might play important roles at different stages (Shearer \& Tippett, 1989) and could affect the potential disease range. Other limiting factors might appear in some areas, such as soil moisture, which has a major role in the natural dissemination of the pathogen and the initiation of the disease at the root level (Shearer \& Tippett, 1989). Indirect effects of climate on host physiology, especially water stress, that were shown to influence disease development (Març

ais et al., 1993; Bunny et al., 1995) should also be included. The improvement of risk projections first relies on the improvement of the epidemiological model. Progress in understanding and managing the effects of global change will require further multidisciplinary efforts to address the challenge of coupling process-based epidemiological models with forest (crop) dynamic growth, climatic and socio-economic models (Goudriaan \& Zadoks, 1995; Coakley \& Scherm, 1996; Pérarnaud et al., 2003).

\section{Acknowledgements}

This study was initiated in the AIP program 'Ecopath', funded by INRA, and was continued as part of the 'CARBOFOR' project funded by the GICC program, French Ministries of Environment and Agriculture. The use of the database from the Département Santé des Forêts is gratefully acknowledged. We thank Doug Bailey for improving the English and two anonymous reviewers for helpful comments on a previous version of the paper.

\section{References}

Anagnostakis SL (1987) Chestnut blight: the classical problem of an introduced pathogen. Mycologia, $79,23-27$.

Augspurger CK (1984) Seedling survival of tropical tree species - interactions of dispersal distance, light-gaps, and pathogens. Ecology, 65, 1705-1712.

Bale JS, Masters GJ, Hodkinson ID et al. (2002) Herbivory in global climate change research: direct effects of rising temperature on insect herbivores. Global Change Biology, 8, 1-16.

Beaumont LJ, Hughes L (2002) Potential changes in the distributions of latitudinally restricted Australian butterfly species in response to climate change. Global Change Biology, 8, 954-971.

Benson DM (1982) Cold inactivation of Phytophthora cinnamomi. Phytopathology, 72, 560-563.

Bergot M, Marçais B, Pérarnaud V et al. (2001) Géographie de l'impact du gel sur la maladie de l'encre du chêne. La Météorologie, VIIlème série, 34, 45-52.

Booth TH, Jovanovic T, Old KM et al. (2000) Climatic mapping to identify high-risk areas for Cylindrocladium quinqueseptatum leaf blight on eucalypts in mainland South East Asia and around the world. Environmental Pollution, 108, 365-372. 
Brasier CM, Robredo F, Ferraz JFP (1993) Evidence for Phytophthora cinnamomi involvement in Iberian oak decline. Plant Pathology, 42, 140-145.

Brasier CM, Scott JK (1994) European oak declines and global warming: a theoretical assessment with special reference to the activity of Phytophthora cinnamomi. Bulletin OEPP, 24, 221-232.

Bunny FJ, Crombie DS, Williams MR (1995) Growth of lesions of Phytophthora cinnamomi in stems and roots of jarrah (Eucalyptus marginata) in relation to rainfall and stand density in Mediterranean forest of Western Australia. Canadian Journal of Forest Research, 25, 961-969.

Chakraborty S, Murray GM, Magarey PA et al. (1998) Potential impact of climate change on plant diseases of economic significance to Australia. Australasian Plant Pathology, 27, 15-35.

Chuine I, Cambon G, Comtois P (2000) Scaling phenology from the local to the regional level: advances from species-specific phenological models. Global Change Biology, 6, 943-952.

Cloppet E (2002) Impact d'un scénario climatique régionalisé 1960- 2100 sur la phénologie et la production primaire de quelques espèces forestières françaises. Note de travail de l'Ecole Nationale de la Météorologie no. 808, 67 pp.

Coakley SM (1988) Variation in climate and prediction of disease in plants. Annual Review of Phytopathology, 26, 163-181.

Coakley SM, Line RF, McDaniel LR (1988) Predicting stripe rust severity on winter wheat using an improved method for analyzing meteorological and rust data. Phytopathology, 78, 543-550.

Coakley SM, Scherm H (1996) Plant disease in a changing global environment. Aspects of Applied Biology, 45, 227-238.

Coakley SM, Scherm H, Chakraborty S (1999) Climate change and plant disease management. Annual Review of Phytopathology, 37, 399-426.

Davis MB, Shaw RG (2001) Range shifts and adaptive responses to Quaternary climate change. Science (Washington), 292, 673-679.

Delatour C (1986) Problem of Phytophthora cinnamomi on red oak (Quercus rubra). Bulletin OEPP, $16,499-504$.

Déqué M, Dreveton C, Braun A et al. (1994) The ARPEGE/IFS atmosphere model: a contribution to the French community climate modelling. Climate Dynamics, 10, 249-266.

Déqué M, Marquet $P$, Jones R (1998) Simulation of climate change over Europe using a global variable resolution general circulation model. Climate Dynamics, 14, 173-189.

Desprez-Loustau ML, Marçais B, Bergot M et al. (2002) Hazard mapping of oak disease and management implications. Les Cahiers du DSF 1-2002, 115-118. La Santé des Forêts en France en 2000 et 2001. Min. Agri. Alim. Pêche Aff. rur. (DERF), Paris, France.

Dobson A, Crawley M (1994) Pathogens and the structure of plant communities. TREE, 9, 393-398.

Erwin DC, Ribeiro OK (1996) Phytophthora Diseases Worldwide. American Phytopathological Society (APS Press), St Paul, MN, USA.

Etterson JR, Shaw RG (2001) Constraint to adaptive evolution in response to global warming. Science (Washington), 294, 151- 154.

Gibelin AL, Déqué M (2003) Anthropogenic climate change over the Mediterranean region simulated by a global variable resolution model. Climate Dynamics, 20, 327-339.

Gilbert GS (2002) Evolutionary ecology of plant diseases in natural ecosystems. Annual Review of Phytopathology, 40, 13-43.

Goudriaan J, Zadoks JC (1995) Global climatic changes: modelling the potential responses of agroecosystems with special reference to crop protection. Environmental Pollution, 87, 215- 224.

Grente J (1961) La maladie de l'encre du châtaignier I Etiologie et biologie. Ann Epiphyties, 5-24.

Hansen EM, Goheen EM (2000) Phellinus weirii and other native root pathogens as determinants of forest structure and process in Western North America. Annual Review of Phytopathology, 38, 515-539.

Harvell CD, Mitchell CE, Ward JR et al. (2002) Climate warming and disease risks for terrestrial and marine biota. Science (Washington), 296, 2158-2162.

Houston DR, Valentine HT (1988) Beech bark disease: the temporal pattern of cankering in aftermath forests of Maine. Canadian Journal of Forest Research, 18, 38-42. 
IPCC (2001) Climate Change 2001. The Scientific Basis. Contribution of Working Group I to the Third Assessment Report of the IPCC (eds Houghton JT, Ding Y, Griggs DJ et al.), Cambridge University Press, Cambridge, UK.

Jahn M, Kluge E, Enzian S (1996) Influence of climate diversity on fungal diseases on field crops evaluation of long-term monitoring data. Aspects of Applied Biology, 45, 247-252.

Johnson DA, Alldredge JR, Vakoch DL (1996) Potato late blight forecasting models for the semiarid environment of SouthCentral Washington. Phytopathology, 86, 480-484.

Kirk PM, Cannon PF, David JC et al. (2001) Ainsworth and Bisby's Dictionary of the Fungi, 9th Edition. CAB International, Egham, UK.

Kramer K (1994a) A modelling analysis of the effects of climatic warming on the probability of spring frost damage to tree species in the Netherlands and Germany. Plant, Cell and Environment, 17, 367-377.

Kramer K (1994b) Selecting a model to predict the onset of growth of Fagus sylvatica. Journal of Applied Ecology, 31, 172-181.

Leblanc DC, Foster JR (1992) Predicting effects of global warming on growth and mortality of upland oak species in the Midwestern United States: a physiologically based dendroecological approach. Canadian Journal of Forest Research, 22, 1739-1752.

Loehle C (1996) Forest response to climate change: do simulations predict unrealistic dieback? Journal of Forestry, 94, 13-15.

Logan JA, Régnie're J, Powell JA (2003) Assessing the impacts of global warming on forest pest dynamics. Frontiers in Ecology and Environment, 1, 130-137.

Machenhauer B, Windelband M, Botzet M et al. (1998) Validation and analysis of regional present-day climate and climate change simulations over Europe. MPI Report 275, Hamburg, 87 pp.

Malmström CM, Raffa KF (2000) Biotic disturbance agents in the boreal forest: considerations for vegetation change models. Global Change Biology, 6 (Suppl. 1), 35-48.

Marçais B, Bouhot-Delduc L, Tacon (Le) F (2001) Possible effects of global change on symbiotic micro-organisms, pathogens and pests in forests. Revue Forestiere Française, 52 (Special), 99- 118.

Marçais B, Dupuis F, Desprez-Loustau ML (1993) Influence of water stress on susceptibility of red oak (Quercus rubra) to Phytophthora cinnamomi. European Journal of Forest Pathology, 23, 295305.

Marçais B, Dupuis F, Desprez-Loustau ML (1996) Modelling the influence of winter frosts on the development of the ink disease of oak, caused by Phytophthora cinnamomi. Annals of Forest Science, 53, 369-382.

Maugard F (1997) Ink disease on pedunculate oak: worrisome news from southwestern France. Les Cahiers du DSF 1-1997, La Santé des Forêts en France en 1996: 29-30. Min. Agri. Pêche (DERF), Paris, France.

Menzel A, Fabian P (1999) Growing season extended in Europe. Nature (London), 397, 659.

Moreau C, Moreau M (1952) Mycological study of ink disease of oak. Revue de Pathologie Vegetale, 31, 201-231.

Mircetich SM, Campbell RN, Matheron ME (1977) Phytophthora trunk canker of Coast Live Oak and Cork Oak trees in California. Plant Disease Reporter, 61, 66-70.

Murray MB, Cannell MGR, Smith RI (1989) Date of Budburst of fifteen tree species in Britain following climatic warming. Journal of Applied Ecology, 26, 693-700.

Parmesan C, Ryrholm N, Stefanescu C et al. (1999) Poleward shifts in geographical ranges of butterfly species associated with regional warming. Nature, 399, 579-583.

Patterson DT, Westbrook JK, Joyce RJV et al. (1999) Weeds, insects, and diseases. Special issue. Climate change: impacts on agriculture. Climatic Change, 43, 711-727.

Peñuelas J, Filella I, Comas P (2002) Changed plant and animal cycles from 1952 to 2000 in the Mediterranean region. Global Change Biology, 8, 531-544.

Pérarnaud V, Seguin B, Malezieux E et al. (2003) Agrometeorological research and applications needed to prepare agriculture and forestry to 21 st century climate change. Proceedings of the International Workshop on Reducing Vulnerability of Agriculture and Forestry to Climate Variability and Climate Change. World Meteorological Organization, Ljubljana, Slovenia, 7-18 October 2002. 
Podger FD, Mummery DC, Palzer CR et al. (1990) Bioclimatic analysis of the distribution of damage to native plants in Tasmania by Phytophthora cinnamomi. Australian Journal of Ecology, 15, 281289.

Podger FD, Newhook FJ (1972) The role of Phytophthora cinnamomi in Australian and New Zealand forests. Annual Review of Phytopathology, 10, 299-326.

Robin C, Desprez-Loustau ML (1999) Risk assessment of Phytophthora cinnamomi dissemination via nursery-grown woody plants. Les Cahiers du DSF 1-1998. La Santé des Fore`ts en France en 1998, pp. 90-92.

Robin C, Desprez-Loustau ML, Capron G et al. (1998) First record of Phytophthora cinnamomi on cork and holm oaks in France and evidence of pathogenicity. Annales des Sciences Forestieres, 55, 869-883.

Robin C, Desprez-Loustau ML, Delatour C (1992a) Spatial and temporal enlargement of trunk cankers of Phytophthora cinnamomi in red oak. Canadian Journal of Forest Research, 22, 362-366.

Robin C, Desprez-Loustau ML, Delatour C (1992b) Factors influencing the enlargement of trunk cankers of Phytophthora cinnamomi in red oak. Canadian Journal of Forest Research, 22, 367374.

Roy DB, Sparks TH (2000) Phenology of British butterflies and climate change. Global Change Biology, 6, 407-416.

Saxe H, Cannell MGR, Johnsen $O$ et al. (2001) Tree and forest functioning in response to global warming. New Phytologist, 149, 369-400.

Scherm H, van Bruggen AHC (1994) Global warming and nonlinear growth: how important are changes in average temperature? Phytopathology, 84, 1380-1384.

Scherm H, Yang XB (1995) Interannual variations in wheat rust development in China and the United States in relation to the El Niño/Southern oscillation. Phytopathology, 85, 970-976.

Shearer BL, Tippett JT (1989) Jarrah dieback: the dynamics and management of Phytophthora cinnamomi in the jarrah (Eucalyptus marginata) forest of south-western Australia. Research Bulletin - Department of Conservation and Land Management, Western Australia, no. 3, 76 pp.

Simmons AJ, Burridge DM (1981) An energy and angular momentum conserving vertical difference scheme and hybrid coordinates. Monthly Weather Review, 109, 758-766.

Smith TM, Reynolds RW, Livezey RE et al. (1996) Reconstruction of historical Sea Surface Temperatures using empirical orthogonal functions. Journal of Climate, 9, 1403-1420.

Sutherst RW, Maywald GF, Yonow T et al. (1999) CLIMEX: Predicting the Effects of Climate on Plants and Animals. CSIRO Publishing, Collingwood, Australia.

Themann K, Werres S, Lu"ttmann A et al. (2002) Observations of Phytophthora spp. in water recirculation systems in commercial hardy ornamental nursery stock. European Journal of Plant Pathology, 108, 337-343.

Timbal J, Bartoli M, Buffet M (1994) Introduction and use of red oak for plantations in France. In: Le chêne rouge (eds Timbal J, Kremer A, Le Goff $\mathrm{N}$ et al.), pp. 15-24. INRA, Paris.

Van der Putten WH, Van Dijk C, Peters BAM (1993) Plantspecific soil-borne diseases contribute to succession in fore-dune vegetation. Nature, 362, 53-56.

Vegh I, Bourgeois M (1975) Preliminary observations on the aetiology of decline in ornamental conifers in French nurseries. Role of Phytophthora cinnamomi Rands. Revue Horticole, 153, 38-49.

Vettraino AM, Barzanti GP, Bianco MC et al. (2002) Occurrence of Phytophthora species in oak stands in Italy and their association with declining oak trees. Forest Pathology, 32, 19-28.

Walther GR, Post E, Convey P et al. (2002) Ecological responses to recent climate change. Nature (London), 416, 389-395.

Weste G, Marks GC (1987) The biology of Phytophthora cinnamomi in Australasian forests. Annual Review of Phytopathology, 25, 207-229.

Zentmyer GA (1980) Phytophthora cinnamomi and the diseases it causes. Monograph, American Phytopathological Society, no. 10, 96 pp. 